\title{
Ağız ve Diş Sağlığı Merkezlerinin Verimlilik Analizi: Marmara Bölgesi Örneği
}

\section{Efficiency Analysis of Oral and Dental Health Centers: Examples of Marmara Region in Turkey}

Oğuzhan Yüksel, ${ }^{\mathrm{a}, *}$ Vahit Yiğit ${ }^{\mathrm{b}}$

${ }^{a}$ Dr., Diş Hekimi, Isparta Ağız ve Diş Sağlığı Merkezi, 32100, Isparta/Türkiye ORCID: 0000-0003-0539-4136

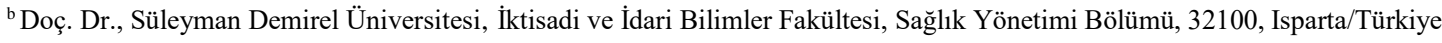
ORCID: 0000-0002-9805-8504

\begin{tabular}{l} 
MAKALE BİLGİSI \\
\hline Makale Geçmişi: \\
Başvuru tarihi: 18 Eylül 2019 \\
Düzeltme tarihi: 20 Şubat 2020 \\
Kabul tarihi: 05 Mart 2020 \\
\hline Anahtar Kelimeler: \\
Ağız ve Diş Sağlığı \\
Teknik ve Tahsis Etkinlik \\
Veri Zarflama Analizi (VZA) \\
Süper Etkinlik
\end{tabular}

\section{A R T I C LE I N F O}

\section{Article history:}

Received 18 September 2019

Received in revised form 20 February 2020

Accepted 05 March 2020

\section{Keywords:}

Oral and Dental Health

Technical and Allocative Efficiency Data Envelopment Analysis (DEA) Super Efficiency
ÖZ

$\mathrm{Bu}$ araştırmanın amacı, Sağlık Bakanlığı'na bağlı Marmara Bölgesi'ndeki Ağız ve Diş Sağlığı Merkezleri'nin 2014 ve 2017 yıllarındaki teknik, tahsis ve ölçek etkinliklerini tespit etmektir. Etkinlik ölçümünde girdi yönelimli Veri Zarflama Analizi (VZA) kullanılmıştır. Araştırmada iki girdi, altı çıktı değişkeni belirlenmiștir. VZA'da verimli bulunan merkezlerin kendi aralarındaki üstünlük sıralaması için süper etkinlik analizi, etkinlik sonuçları ile girdi/çıktı değişkenleri arasındaki ilişkiyi tespit etmek içinse regresyon analizi yapılmıştır. Araştırma sonucunda 33 merkezin 2014 yılı ortalama teknik etkinliği 0,909, tahsis etkinliği 0,945 ve ölçek etkinliği 0,960 olarak tespit edilmiştir. Merkezlerin 2017 yılındaki ortalama teknik etkinliği 0,916, tahsis etkinliği 0,954 ve ölçek etkinliği 0,960 olarak saptanmıştır. Verimsiz olan merkezler; teknik, tahsis ve ölçek verimliliğini sağlayabilmek için referans kümesini esas alarak gerekli potansiyel iyileştirmeleri yapmalıdırlar.

\begin{abstract}
A B S T R ACT
The aim of this research is to determine the technical, allocative and scale efficiency of Oral and Dental Health Centers in Marmara region under the Turkish Ministry of Health in 2014 and 2017. Input-oriented Data Envelopment Analysis (DEA) method was used for efficiency measurement. Two inputs and six output variables were used in the study. Super efficiency analysis was performed to rank the advantages among the centers found to be efficient as a result of DEA, and regression analysis was performed to determine the correlation between the efficiency results and the input/output variables. As a result of the research, the average technical efficiency of 33 centers in 2014 was 0,909 , allocative efficiency 0,945 and scale efficiency 0,960 . In 2017 , the centers had an average technical efficiency of 0,916 , allocative efficiency of 0,954 and scale efficiency of 0,960 . Inefficient centers must make the necessary potential improvements based on the reference set in order to achieve technical, allocative and scale efficiency.
\end{abstract}

\section{Giriş}

Ülkelerin gelişmişlik düzeylerinde önemli bir gösterge olan sağlık sektöründe yapılacak iyileştirmeler ve düzenlemeler için mevcut kaynakların etkin ve verimli kullanması gerekmektedir (Yıldırım ve Yıldırım, 2011: 83). Sağlık sektörünün büyümeye devam edeceğini göz önüne aldığımızda yüksek kaliteli, uygun maliyetli sağlık hizmeti verilebilmesi önem kazanmaktadır. Sağlık sisteminin sürekli bir iyileştirme süreci gerektirdiği konusunda dünyada genel bir fikir birliği vardır (Naveh ve Stern, 2005: 249-250). Hastanelerin performansının değerlendirilmesi, sağlıkla ilgili belirlenecek politikalar ve alınacak kararlar bakımından önemlidir (Ağaç ve Baki 2016: 343). Türkiye'de hastanelerin finansman kaynağını oluşturan geri ödeme kuruluşlarının imkânlarının sınırlı olması, maliyet azaltıcı sağlık politikaları üretilmesine sebebiyet vermektedir. Özellikle günümüzde, hastanelerin finansal performansının

\footnotetext{
* Sorumlu yazar/Corresponding author.

e-posta: oguzhan@doctor.com
} 
bu yöntemlerden etkilendiğini söylemek yanlış olmaz (Yiğit ve Yiğit, 2016: 254).

Kısıtlı kamu kaynaklarını kullanarak en yüksek faydayı sağlamak isteyen hastane idarecileri için girdilerin çıktılara dönüştürülmesi sürecindeki başarıyı ifade eden verimlilik kavramının önemi son yıllarda giderek artmaktadır (Sezen ve Gök, 2009: 383). Verimlilik uygulamalarının hastane genelinde uygulanmasının yanında birim bazında ayrı ayrı yapılması ile daha doğru sonuçlar elde edilecektir. Sonuçlar 1şı̆̆ında uygun iyileştirme faaliyetleri yapılırken kaliteli hizmet sunumundan da taviz verilmemelidir (Ağırbaş, 2014: 21).

Türkiye'de sağlık hizmetlerinin verilmesi ve denetiminden Sağlık Bakanlığı (SB) sorumludur. Ağız ve diş sağlığı (ADS) hastalıklarının önlenebilmesi ve tedavisi de sorumluluk sınırları içerinde yer almaktadır. Birçok gelişmiş ve gelişmekte olan ülke, ADS düzeyinin optimal şartlara gelmesi için büyük bütçeler ayırmaktadır (Çolak vd., 2010: 63).

ADS hastalıkları toplumda çok yaygın görülen problemlerdendir. Kişilerin çocukluktan yaşlılığa tüm yaşamı boyunca genel sağlığına ve hayat kalitesine doğrudan etki etmektedir. WHO, dünya genelinde okul çağındaki çocukların \% 60-90’1 ve neredeyse erişkinlerin tamamında diş çürükleri olduğunu, 65-74 yaş arasındaki kişilerin ise yaklaşı1k \% 30'unda ana dişlerinin kaybedilmiş olduğunu söylemektedir. Genellikle ADS, bireyler tarafından hayati tehlike yaratmayacağı düşünüldüğünden çok önemsenmemektedir. Toplumdaki genel kabul gören inanışın aksine, basit sanılan bir diş çürüğü vücuttaki diğer organlarda enfeksiyona ve çeşitli hastalıklara neden olabilmektedir (T.C. Sağlık Bakanlığı, 2016: 51). Sağlık problemlerinde kişisel tutumlar sabit değildir. Zamana, alışkanlıklara, beklentilere, adaptasyona bağlı olarak değişir (Allen, 2003: 1). Kişinin sağlıklı olması denildiğinde ağız ve çevreleyen dokuların da sağlıklı olduğu anlaşılmalıdır. Çünkü sağlıksız ağız ve diş yapısına sahip bir bireyin sağlıklı olduğu söylenemez. Genel sağlık ile ağız sağlığı bir bütündür ve birbirini tamamlamaktadır (Locker, 1997: 17).

Türkiye'de ADS hizmetleri Sağlık Bakanlığı bünyesinde bulunan klinikler, özel ve devlete ait üniversitelerde bulunan diş hekimliği fakülteleri, bazı belediyelerce kurulmuş sağlık tesisleri ve özel muayenehaneler/poliklinikler vasıtası ile verilmektedir. T.C. SB Kamu Hastaneleri Genel Müdürlüğü'nün 2017 tarihli istatistik raporuna göre ADS hizmetleri; ülke genelinde devlete ait 132 adet Ağız ve Diş Sağlığı Merkezi (ADSM), 22 Ağız ve Diş Sağlığı Hastanesi (ADSH), 510 adet ADS polikliniği bulunan devlet hastanesinde 9.432 ünit sayısı ile yürütülmektedir. 2017 yılı boyunca Türkiye genelinde, 7.844 diş hekimi ve 841 uzman diş hekimi ile 27.273.879 hasta sayısına ulaşılmıştır. Araştırmada kullanılan değişkenlere ilişkin, Marmara Bölgesi'nde bulunan toplam 41 tane ADSM'nin 2017 yılı hizmet göstergelerine bakıldığındaysa; 1.983 toplam ünit sayısı ve 1.884 toplam diş hekimi sayısı ile 5.574.300 toplam hasta sayısına ulaşıldığı görülmüştür (www.khgm.saglik.gov.tr, 19.05.2019).

Türk Diş Hekimleri Birliği’nin (TDB) 2018 yılına ait istatistiki bilgileri içeren yayınına göre, Türkiye'deki diş hekimlerinin \%52'sinin özel sektörde, \%32'sinin Sağlık Bakanlığı'nda, \%14'ünün Diş Hekimliği Fakülteleri'nde, \%2'sinin de diğer kurumlarda çalıștıkları görülmektedir. Mesleğini aktif olarak yapan 34.034 diş hekiminin \%58'i erkek, \%42'si kadındır ve 17.884 tanesi özel sektörde çalışmaktadır (TDB, 2019: 2-12).

Bu çalışma ile Türkiye'de ADS hizmet sunumunda büyük paya sahip ADSM'lerde verilen hizmetlerin 2014 ve 2017 yılları verileri birbiri ile kıyaslanarak analizin evreni olarak seçilen Marmara Bölgesi özelinde değerlendirilmesi amaçlanmaktadır. Sağlık Bakanlığı'nın bütçe yaklaşımları ADS hizmeti sunan kurumların da mali açıdan çeşitli önlemler almasını zorunlu kılmaktadır. ADS ile ilgili hizmetlerin, gelecekte daha etkili şekilde planlanabilmesi açısından teknik verimlilik analizleri önemlidir. Etkin ve etkili bir sistemin verimlilik sayesinde tesis edilebileceği düşünülmüş, kaynakların doğru kullanılması gerektiği vurgulanmış ve VZA yöntemi ile verimlilik ölçümleri yapılmaya çalışılmıştır. Verimli olan merkezlerin üstünlükleri bakımından sıralamaları yapılmış, referans kümeleri belirlenerek çözüm önerileri geliştirilmiştir.

\section{Veri Zarflama Analizi}

Veri Zarflama Analizi (VZA), Edward Rhodes'un doktora tezi çalışmalarında kullandığı regresyon ve korelasyon tekniklerinden istediği sonuçları alamaması neticesinde, Farrell'in 1957 'de yazdığı makaleyi fark etmesiyle temelleri atılan bir yöntemdir (Cooper, 2005: 5-6). "The Measurement of Productive Efficiency" adlı Farrell'in (1957: 253-281) çalışması kaynak alınarak yola çıkan Charnes, Cooper ve Rhodes 1978 yılında literatürde CCR modeli olarak bilinen, ölçeğe göre sabit getiri (Constant Return to Scale: CRS) durumunu ele alan çalışmayla VZA modelini ortaya çıkarmışlardır. İlerleyen yıllarda Banker, Charnes ve Cooper (BCC modeli) ise çalışmalarında ölçeğe göre değişken getiriyi (Variable Return to Scale: VRS) değerlendirmişlerdir. CCR ve BCC modelleri yardımıyla VZA kullanılarak yapılan çalışmalarda farklı neticeler görülebilmektedir (Temür, 2010: 10, Ramanathan, 2005: 41).

VZA non-parametrik, doğrusal programlama tabanlı bir analiz yöntemidir. $\mathrm{Bu}$ teknik, Karar Verme Birim (KVB)'lerinin birbirleri ile karşılaştırılmasını sağlar. KVB'ler çoklu girdileri çoklu çıktılara dönüştürme yeteneğine sahip, aynı pazar şartları altında, aynı amaçla benzer işleri yapan, bağımsız organizasyonlardır. KVB'ler belirlendikten sonra, VZA kullanılarak her bir organizasyon en iyi olan ile karşılaştırılabilir. VZA tekniği, bir sınır (frontier) belirleyerek her bir KVB'nin verimliliğini belirlenen sınıra olan uzaklığı nispetinde göreceli analiz eder. Yöntem, geleneksel analizlerin çoklu girdi ve çıktıların değerlendirilmesi için sağlayamadıkları bütünselliği, toplam faktör verimliliği mantığı ile yerine getirebilmektedir (Babacan, 2006: 29-30).

KVB'ler arasından en az girdi ile en çok çıktıya ulaşan birimler belirlenmektedir. En iyi birimler 1 veya 100 değeri alarak etkinlik sınırını oluşturmaktadırlar. Etkin olmayan KVB'ler ise 1'den küçük değerler almaktadırlar. KVB analiz sonucu 1'den ne kadar küçükse etkinlik sınırına o kadar uzak olduğu anlaşılmaktadır (Sherman, 1984: 925).

VZA modeli girdiye (input oriented) veya çıktıya (output oriented) yönelik olabilmektedir. Girdiye yönelik modelde, en yüksek çıktıya ulaşabilmek için gerekli olan en uygun 
girdi bileşimi esas alınırken çıktıya yönelik modelde eldeki girdilerle en fazla çıktının nasıl elde edilebileceği belirlenmeye çalışılmaktadır (Kavuncubaşı ve Ersoy, 1995: 82).

Literatürdeki çalışmalar incelendiğinde, VZA yönteminin özellikle hastanelerde, banka şubelerinde, sanayi tesislerinde, üniversitelerde, okullar arasında yapilan analizlerde fazlaca kullanıldığı görülmektedir (Kutlar ve Kartal, 2004: 50, Thanassoulıs, 1993: 1129). Kamu kurumlarındaki sağlık hizmetlerinin değerlendirilmesinde, yöntemin hastane idarecileri için önemi gittikçe artmaktadır (Flokou vd.,2017: 5).

Şekil 1'de görüldüğü üzere A, B, C, D noktaları KVB gözlem kümesini oluşturmaktadır. $\mathrm{BCC}$ modeline (VRS) göre etkinlik sınırının üzerinde bulunan A, B ve C KVB'leri teknik olarak etkindir. Aynı gözlem kümesinde CCR modeli (CRS) uygulandığında ise 0 ile $\mathrm{B}$ noktası üzerinden geçen doğru etkinlik sınırı olacaktır. Bu durumda $\mathrm{BCC}$ modeline göre etkin olan A ve C noktaları, CCR modeline göre etkin olmayan KVB'ler arasında yer almaktadır.

VZA uygulama aşamaları; güvenilir verilere ulaşılması, KVB'lerin seçimi, girdi ve çıktı değişkenlerinin tespit edilmesi, uygun VZA yönteminin belirlenerek uygulamanın yapılması ve elde edilen sonuçların değerlendirilmesi şeklinde sıralanabilir (Yolalan, 1993: 61-66).

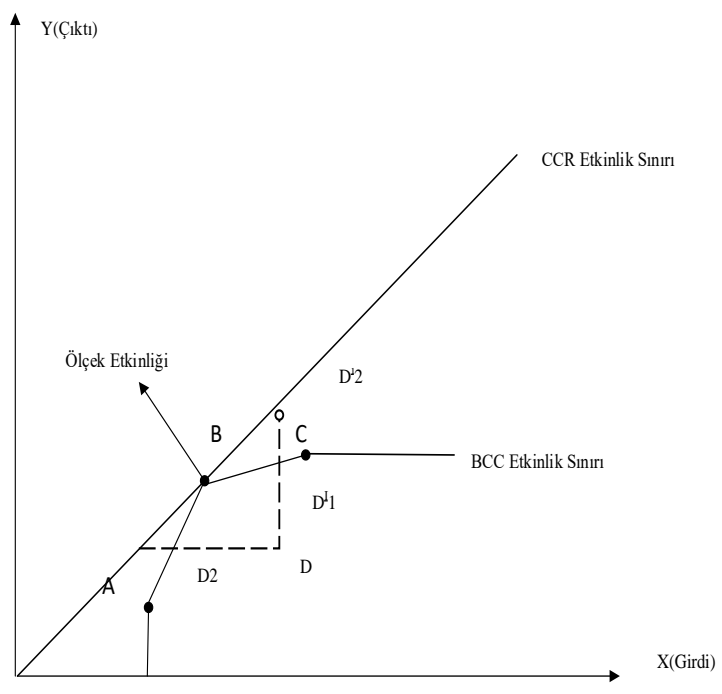

Şekil 1. VZA'nın Grafiksel Gösterimi (Kaynak: Şahin, 2008: 18)

\section{Yöntem}

Türkiye İstatistik Kurumu (TÜİK) verilerine göre 2017 y1lında Türkiye nüfusu toplam 80.810 .525 'dir. İstanbul, Bursa, Kocaeli, Tekirdağ, Edirne, Kirklareli, Yalova, Balıkesir, Bilecik, Çanakkale ve Sakarya illerinin bulunduğu Marmara bölgesinde; verilerini kullandığımız 2017 yılı itibariyle 24.816.023 kişi yaşamaktadır. Bölge nüfusu, tüm ülke nüfusunun yaklaşık \%31'ine tekabül etmektedir. Türkiye nüfusunun neredeyse 1/3'ünü kapsaması nedeniyle Marmara Bölgesi incelemeye alınmıştır.
Araștırmanın amacı, 2014 ve 2017 yıllarında Marmara Bölgesi'nde hizmet veren ağı ve diş sağlığ verimliliklerini belirlemek, etkinlik sınırının altında kalanların verimsizliklerinin kaynağını tespit etmek ve çözüm önerileri geliştirmektir. Marmara Bölgesi genelinde ADS hizmetleri sunumunda, ADSM'lerin yeri anlaşılmaya çalışılmış, birbirine benzer merkezler aynı girdi ve çıktılar eşliğinde değerlendirmeye tabi tutulmuş, VZA ile teknik verimliliklerinin karşılaştırılması hedeflenmiştir. Araştırmada EMS (Efficiency Measurement System) paket programından yararlanılmıştır. Veriler Microsoft Excel programında düzenlenmiş, sonrasında Excel dosyaları EMS paket programına aktarılarak etkinlik ölçümleri yapılmıştır. Marmara Bölgesi'nde ADSM'lerin toplam girdi ve çıktı değişkenleri hesaplanarak, teknik verimlilik değerlendirilmesinde VZA yöntemi kullanılmıştır.

Araştırmada ADSM'lerin 2014 ve 2017 yılı karşılaştırmaları yapilırken, bu merkezlerin her iki dönemde de hizmet sunması esas alınmıştır. Marmara Bölgesi'ndeki 2014 yılında faaliyette olan 35 ADSM'nin 33 tanesi araştırma kapsamına dâhil edilmiştir. Kocaeli'nde bulunan Gölcük ADSM 2014 yılının 11. Ayında açıldığından örneklem kümesine alınmamıştır. Ayrıca Üsküdar Ahmet Yüksel Özemre ADSM'nin 2014 yılı verilerine ulaşılamadığından KVB'ler arasında değildir. 2014 yılında Marmara Bölgesi ADSM sayısı dikkate alındığında evrenin \%94,2'sinin temsil edildiğini söyleyebiliriz. 2014 ve 2017 yılları arasında yaşanan isim değişiklikleri (bazı merkezlerin hastane statüsüne geçmeleri) göz ardı edilmiştir. Makale genelinde ADSH'lardan da kavram karmaşası olmaması açısından ADSM olarak bahsedilmiştir. Araştırma verileri 2014 ve 2017 yılı SB Kamu Hastaneleri istatistik raporlarından elde edilmiştir. Verilerin \%100 doğru olduğu varsayılmıştır.

Devlet hastaneleri ve eğitim-araştırma hastaneleri içerisinde bulunan ADS klinikleri ile SB'na bağlı olmayan ADSM, ADSH ve özel diş klinikleri/poliklinikleri araştırma evrenine dâhil edilmemiştir. 2014 sonrasında açılan merkezler de kapsam dışında bırakılmıştır. Aynı yasalarla ve yönetmeliklerle çalışmaları, aynı coğrafi bölgede hizmet vermeleri, hemen hemen aynı büyüklükte merkezler/hastaneler olmaları nedeniyle, 2014 ve 2017 yıllarında SB'na bağlı olarak hizmet veren Marmara Bölgesi'ndeki ADSM'leri ile araştırma sınırlandırılmıştır.

VZA'nde kullanılmak üzere girdi değişkenleri olarak; diş üniti sayısı ve toplam diş hekimi sayısı alınmıştır. Çıktı değişkenleri olarak ise; hasta sayısı, diş çekimi sayısı, dolgu tedavisi sayısı, kanal tedavisi sayısı, sabit protez üye sayısı ve hareketli protez parça sayısı alınmıştır. Araştırmada, ADSM'lerin teknik verimliliği ölçüldüğü için diş çekimi sayısı (gereksiz çekim yapılmadığı ve yalnızca tedavi edilerek kurtarılamayacak durumdaki dişlerin çekildiği varsayılarak) değişkenler içerisine dâhil edilmiştir. Şekil 2'de çalışmada kullanılan girdi ve çıktı değişkenleri gösterilmiştir. 


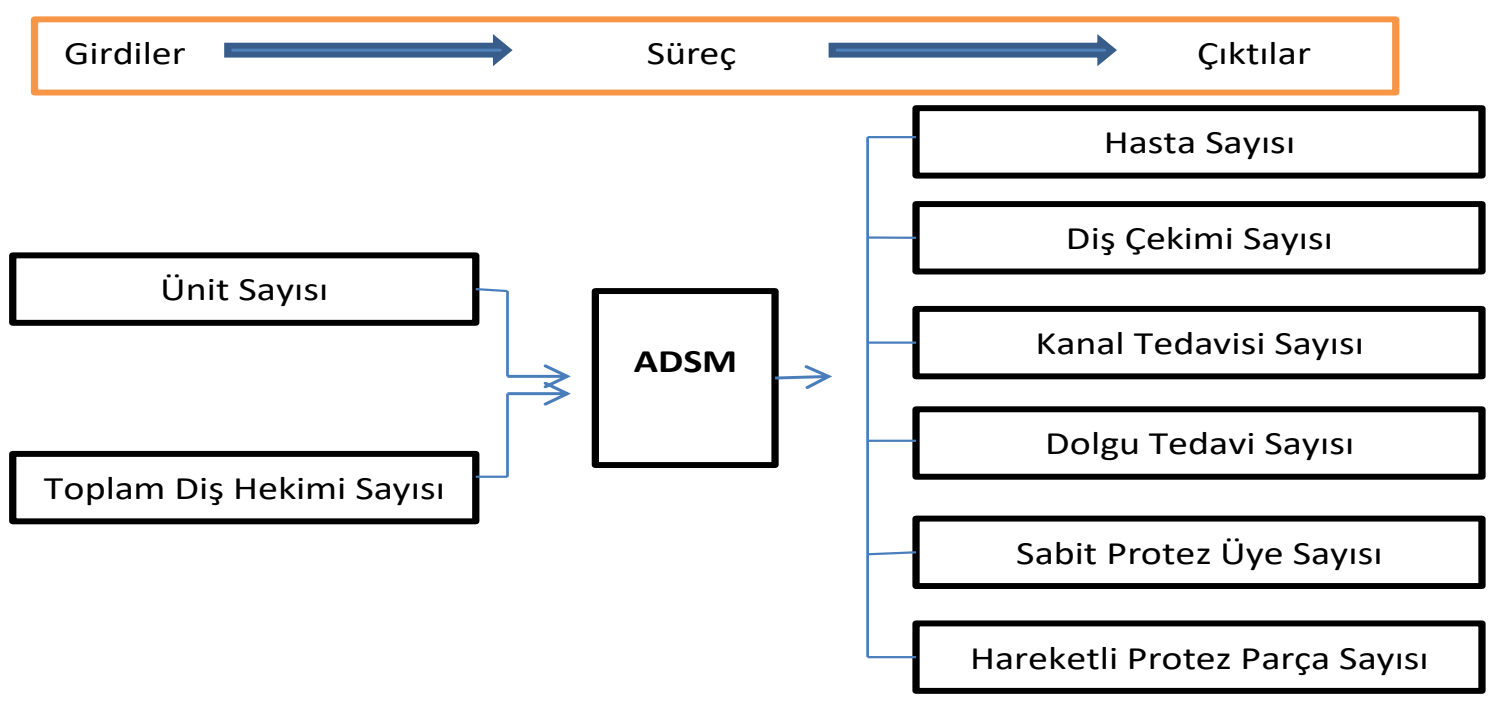

Şekil 2. Çalışmada Kullanılan Girdiler ve Çıktılar

Girdi değişkenleri içerisinde yer alan ünit sayısı; diş hekimliğinde kullanılan muayene ve tedavilerin yapıldığ hasta koltuğu sayısını, toplam diş hekimi sayısı; ilgili merkezdeki uzman ve pratisyen diş hekimlerinin tamamının sayısını, sabit protez üye sayısı; ağızdaki diş kayıplarında uygulanan porselen, laminate vb. hammaddelerden üretilmiş olan, diş eksikliği yapıştırma protezler yoluyla giderilen toplam diş sayısını ve hareketli protez parça sayısı ise alt ve üst çene ayrı ayrı sayılmak kaydı ile takıp çıkartılabilen damak diş sayısını göstermektedir.

Marmara Bölgesi'nde bulunan örnekleme dahil edilen 33 tane ADSM'nin tamamı düşünüldüğünde, ortalama ünit sayısının 2014 yılında 41 iken 2017 yılında 50'ye, toplam diş

Tablo 1. Girdi ve Çıktı Değişkenlerinin İstatistiki Bilgileri hekimi sayısının 2014 yilında 1.360'dan 2017 yılında 1.663 'e, hasta sayısının 2014 yılında ortalama 122.680 iken 2017 yılında 144.029'a, ortalama diş çekimi sayısının 2014 yılında 38.460'dan 2017 yılında 38.900'e, ortalama kanal tedavisi yapılan diş sayısının 2014 yılında 11.773 iken 2017 yılında 18.076'ya, dolgu yapılan ortalama diş sayısının 2014 y1lında 50.754 iken 2017 y1lında 73.055 'e, sabit protez üye sayıs1 ortalamasının 2014 y1lında 37.178'den 2017 y1lında 46.379'a, hareketli protez parça sayısı ortalamasının ise 2014 yılında 3.680'den 2017 yılında 3.739'a yükseldiği görülmüştür. Ayrıca KVB'lere ait standart sapma, minumum ve maksimum değerleri içeren bilgiler Tablo 1'de sunulmuştur.

\begin{tabular}{|c|c|c|c|c|c|c|c|c|c|}
\hline & \multirow{2}{*}{ Değişkenler } & \multicolumn{2}{|c|}{ Ortalama } & \multicolumn{2}{|c|}{ Std. Sapma } & \multicolumn{2}{|c|}{ Min. } & \multicolumn{2}{|c|}{ Maks. } \\
\hline & & 2014 & 2017 & 2014 & 2017 & 2014 & 2017 & 2014 & 2017 \\
\hline \multirow{2}{*}{ Girdi } & Ünit Sayıs1 & 41,091 & 50,394 & 33,696 & 38,192 & 14 & 18 & 184 & 211 \\
\hline & Toplam Diş Hekimi Sayısı & 41,212 & 47,03 & 34,136 & 38,861 & 14 & 14 & 182 & 218 \\
\hline \multirow{6}{*}{ Çıktı } & Hasta Sayıs1 & $122.680,4$ & $144.029,1$ & $96.837,3$ & $91.491,3$ & 41.745 & 57.673 & 467.570 & 467.121 \\
\hline & Diş Çekimi Sayısı & $38.460,4$ & $38.900,8$ & $32.074,8$ & $26.220,2$ & 12.812 & 15.522 & 146.533 & 138.399 \\
\hline & Kanal Tedavisi Sayısı & $11.773,5$ & $18.076,8$ & $11.371,1$ & $15.670,4$ & 2.637 & 2.766 & 61.396 & 86.642 \\
\hline & Dolgu Tedavi Sayısı & $50.754,9$ & $73.055,4$ & $45.532,0$ & $52.273,5$ & 13.858 & 15.699 & 247.736 & 268.896 \\
\hline & Sabit Protez Üye Sayısı & $37.178,9$ & $46.379,5$ & $36.118,6$ & $40.561,6$ & 10.446 & 14.658 & 195.019 & 216.176 \\
\hline & Hareketli Protez Parça Sayısı & $3.680,5$ & $3.739,4$ & $3.024,5$ & $3.162,9$ & 699 & 768 & 14.876 & 17.835 \\
\hline
\end{tabular}




\section{Bulgular}

Girdi ve çıktı değişkenleri analizi; girdiye yönelik VZA çerçevesinde, 2014 ve 2017 yılları ayrı ayrı ele alınarak hem CCR modeli ve hem BCC modelleriyle hesaplanmıştır. Marmara Bölgesi kapsamına giren 11 il içerisinde, araştırma evrenine dâhil edilen 33 tane ADSM KVB'leri oluşturmuştur.

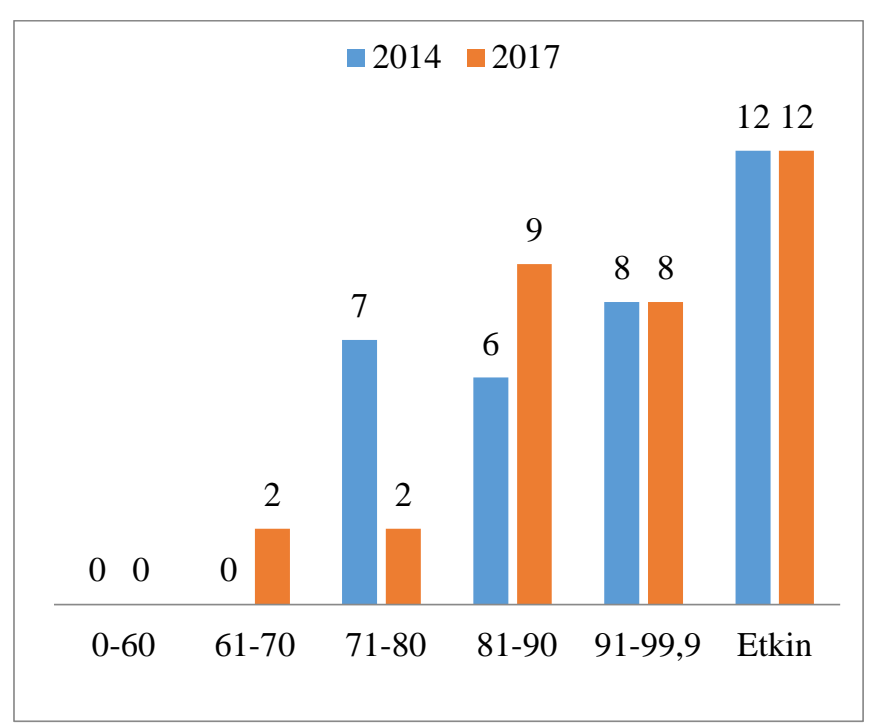

Şekil 3. 2014 ve 2017 Yılları CCR Model Sonuçlarına Göre Yüzdelik Dilimlerdeki ADSM Sayıları
2014 yılı sonuçlarına bakıldığında CCR modeline göre toplam $12 \mathrm{KVB}$, BCC modeline göre $19 \mathrm{KVB}$ tam etkin çalışmaktadır. 2017 yılı sonuçlarına göre ise CCR modeline göre toplam $12 \mathrm{KVB}$, BCC modeline göre $18 \mathrm{KVB}$ 'nin tam etkin çalıştığ tespit edilmiştir (2017 yılına ait CCR modeline göre tam etkin bulunan KVB listesinin siralaması süper etkinlik tablosunda verilmiştir). 2014 yılında $\% 71$ ve altında verimlilikle çalışan KVB yokken, 2017 yılında 2 KVB \% 71 ve altında verimlilik göstermiştir. Hem 2014 hem 2017 yıllarında CCR modeline göre \%61'den düşük skora sahip KVB olmadığg görülmektedir. Yüzdelik dilimlere göre KVB sayıları Şekil 3 'te gösterilmiştir.

CCR modelinde merkezlerin 2014 ve 2017 yıllarında $\% 36,6$ 'si, BCC modelinde ise 2014 y1lında merkezlerin $\% 57,57$ 'si, 2017 yılında ise \%54,54'ü verimlidir. 2014 yılı CCR modeli sonuçlarına göre en verimsiz KVB'ler İstanbul Çekmeköy ADSM (\%73,81), İstanbul D.A.H. Ceylan ADSM $(\% 74,36)$, Çanakkale ADSM $(\% 74,55)$ olarak belirlenmiştir. 2017 yılı CCR modeli sonuçlarına göre değerlendirildiğinde ise en verimsiz KVB'lerin; İstanbul Ataşehir ADSH $(\% 66,19)$, Çanakkale ADSM $(\% 69,84)$, İstanbul Göztepe ADSM $(\% 74,39)$ olduğu anlaşılmıştır. VZA ile yapılan analiz sonuçları genel olarak Tablo 2'de gösterilmektedir.

Tablo 2. Marmara Bölgesi ADSM'leri CCR ve BCC Model Sonuçları Özet Tablosu

\begin{tabular}{|c|c|c|c|c|}
\hline & \multicolumn{2}{|c|}{ CCR } & \multicolumn{2}{|c|}{ BCC } \\
\hline & 2014 & 2017 & 2014 & 2017 \\
\hline Marmara Bölgesi İl Sayısı & 11 & 11 & 11 & 11 \\
\hline KVB Sayıs1 & 33 & 33 & 33 & 33 \\
\hline KVB Ortalama Verimlilik Skoru & 0,909 & 0,916 & 0,945 & 0,954 \\
\hline En Düşük Verimlilik Skoru & 0,738 & 0,661 & 0,774 & 0,707 \\
\hline Verimli KVB Sayısı & 12 & 12 & 19 & 18 \\
\hline Verimsiz KVB Sayısı & 21 & 21 & 14 & 15 \\
\hline Verimsiz KVB Yüzdesi (\%) & 63,63 & 63,63 & 42,42 & 45,45 \\
\hline Verimsiz KVB Ortalama VZA Skoru & 0,864 & 0,868 & 0,871 & 0,899 \\
\hline
\end{tabular}

Marmara bölgesinde bulunan 11 ilin tamamından en az bir KVB araştırma kapsamına girmiştir. Bölgedeki en büyük il olması hasebiyle İstanbul'dan toplam $13 \mathrm{KVB}$ örneklem kümesindedir. İstanbul'u 4 KVB ile Kocaeli takip ederken; Çanakkale, Sakarya, Yalova, Bilecik ve Edine illerinden yalnızca 1 KVB analize dâhil edilmiştir. 2014 ve 2017 yıllarına ait sonuçlarının tamamı göz önüne alındığında, hem BCC yöntemi hem CCR yöntemi analizlerinde İstanbul
Bahçelievler ADSM, Balıkesir ADSM, Balıkesir Edremit A.F. Akıllığlu ADSM, Bursa ADSM, Kırklareli ADSM, Kocaeli Nuh Çimento Sanayi Vakfı ADSM, Kocaeli Darıca ADSM, Tekirdağ Çerkezköy ADSM isimli KVB'lerin verimli oldukları görülmektedir. 2014 ve 2017 yıllarına ait KVB kodları, KVB isimleri, bulundukları iller, CCR, BCC ve Ölçek Verimliliği (ÖV) analiz sonuçları Tablo 3'te gösterilmektedir. 
Tablo 3. 2014 ve 2017 Yıllarına Ait Analiz Sonuçları

\begin{tabular}{|c|c|c|c|c|c|c|c|c|}
\hline \multirow{2}{*}{ Kodu } & \multirow{2}{*}{ KVB Adı } & \multirow{2}{*}{ Bulunduğu İl } & \multicolumn{3}{|c|}{2014} & \multicolumn{3}{|c|}{2017} \\
\hline & & & CCR & BCC & ÖV & CCR & BCC & ÖV \\
\hline M1 & D.A.H. Ceylan & İstanbul & 0,74 & 0,82 & 0,91 & 0,83 & 0,98 & 0,84 \\
\hline M2 & Bahçelievler & İstanbul & 1 & 1 & 1 & 1 & 1 & 1 \\
\hline M3 & Göztepe & İstanbul & 0,85 & 0,85 & 0,99 & 0,74 & 0,75 & 0,99 \\
\hline M4 & Kartal & İstanbul & 0,78 & 0,79 & 0,99 & 0,95 & 1 & 0,95 \\
\hline M5 & Sancaktepe & İstanbul & 0,9 & 1 & 0,9 & 1 & 1 & 1 \\
\hline M6 & Güngören & İstanbul & 0,97 & 1 & 0,97 & 1 & 1 & 1 \\
\hline M7 & Beykoz & İstanbul & 0,92 & 0,93 & 0,99 & 0,94 & 0,96 & 0,97 \\
\hline M8 & Beylikdüzü & İstanbul & 1 & 1 & 1 & 0,93 & 0,93 & 1 \\
\hline M9 & Topçular & İstanbul & 0,96 & 1 & 0,96 & 0,85 & 0,87 & 0,97 \\
\hline M10 & Çekmeköy & İstanbul & 0,74 & 0,82 & 0,9 & 0,98 & 1 & 0,99 \\
\hline M11 & Avcılar & İstanbul & 0,79 & 0,82 & 0,97 & 1 & 1 & 1 \\
\hline M12 & Ataşehir & İstanbul & 0,84 & 1 & 0,84 & 0,66 & 0,89 & 0,74 \\
\hline M13 & Okmeydanı & İstanbul & 0,93 & 1 & 0,93 & 0,85 & 1 & 0,85 \\
\hline M14 & Balıkesir & Balıkesir & 1 & 1 & 1 & 1 & 1 & 1 \\
\hline M15 & Edremit A.F.Ak1llığlu & Balıkesir & 1 & 1 & 1 & 1 & 1 & 1 \\
\hline M16 & Bandirma & Balıkesir & 0,91 & 1 & 0,91 & 0,88 & 0,95 & 0,93 \\
\hline M17 & Bilecik & Bilecik & 0,76 & 0,79 & 0,96 & 0,93 & 1 & 0,93 \\
\hline M18 & Bursa & Bursa & 1 & 1 & 1 & 1 & 1 & 1 \\
\hline M19 & Duaçınarı & Bursa & 0,92 & 0,97 & 0,95 & 1 & 1 & 1 \\
\hline M20 & İnegöl & Bursa & 0,84 & 0,86 & 0,97 & 0,93 & 0,94 & 1 \\
\hline M21 & Çanakkale & Çanakkale & 0,75 & 0,77 & 0,96 & 0,7 & 0,71 & 0,99 \\
\hline M22 & Edirne & Edirne & 0,81 & 0,88 & 0,92 & 0,77 & 0,78 & 0,98 \\
\hline M23 & Kırklareli & Kırklareli & 1 & 1 & 1 & 1 & 1 & 1 \\
\hline M24 & Lüleburgaz & Kirklareli & 0,82 & 0,99 & 0,83 & 0,9 & 0,96 & 0,94 \\
\hline M25 & Nuh Çimento San. Vakfi & Kocaeli & 1 & 1 & 1 & 1 & 1 & 1 \\
\hline M26 & Darıca & Kocaeli & 1 & 1 & 1 & 1 & 1 & 1 \\
\hline M27 & Derince & Kocaeli & 1 & 1 & 1 & 0,9 & 1 & 0,9 \\
\hline M28 & Körfez & Kocaeli & 0,98 & 1 & 0,98 & 0,85 & 1 & 0,85 \\
\hline M29 & Sakarya & Sakarya & 0,83 & 0,92 & 0,9 & 0,95 & 1 & 0,95 \\
\hline M30 & Tekirdağ & Tekirdağ & 1 & 1 & 1 & 0,87 & 0,89 & 0,98 \\
\hline M31 & Çorlu & Tekirdağ & 1 & 1 & 1 & 0,86 & 0,89 & 0,97 \\
\hline M32 & Çerkezköy & Tekirdağ & 1 & 1 & 1 & 1 & 1 & 1 \\
\hline M33 & Yalova & Yalova & 0,97 & 1 & 0,97 & 0,98 & 0,99 & 0,99 \\
\hline
\end{tabular}

Etkin olmayan ADSM'lerin etkin hale gelebilmeleri için yapmaları gereken potansiyel iyileştirmeler hesaplanmıştır. Etkin olmak için benzemeye çalışacakları KVB'ler referans kümesinde belirtilmiştir. Böylece ADSM'ler arasında rekabet edebilirliği gündeme taşıyıp bölge genelinde ADS çalışmalarının daha iyi seviyelere çıkarılması amaçlanmıştır. Sonuçların sonraki yıllarda, kaynak dağıtım politikalarında kaynakların en doğru olarak hangi ADSM'ye hangi miktarlarla aktarılması gerektiği konusunda karar vericilere yol göstermesi beklenmektedir.

ADSM'ler içerisinden CCR modeli temel alındığında; 2014 yılında etkin oldukları sonucuna varılan 12 tane ADSM'den 11 tanesinin çeşitli hastanelere referans gösterildiği gözlenmektedir. Tekirdağ Çerkezköy ADSM etkin olmasına rağmen diğer hastaneler tarafından referans alınmayan tek hastane olarak karşımıza çıkmaktadır. Buna karşılık
Balıkesir Edremit A.F. Akıllıŏlu ADSM diğer 16 KVB için referans gösterilirken, Kocaeli Darıca ADSM ve Kırklareli ADSM yalnızca $1 \mathrm{KVB}$ için referans gösterilmiştir. 2017 yılı CCR sonuçlarına bakıldığında ise; yine etkin oldukları sonucuna varılan 12 ADSM'nden 11 tanesinin çeşitli hastanelere referans gösterildiği gözlenmektedir. Burada İstanbul Güngören ADSM diğer hastanelerce refere edilmeyen tek hastane olarak karşımıza çıkmaktadır. Tekirdağ Çerkezköy ADSM 16 diğer merkez için referans gösterilmiş, Bursa ADSM, Kocaeli Darıca ADSM ve Kocaeli Nuh Çimento Sanayi Vakfi ADSM sadece 1 KVB tarafından referans alınmıştır. Tablo 5'de CCR modeline göre, 2014 ve 2017 yıllarındaki verimli KVB'lerin referans gösterilme sıklıkları yer almaktadır. Tablo 4 'te CCR modeli sonuçlarına göre referans sıklıkları 2014 ve 2017 yılları için ayrı ayrı verilmiştir. 
Tablo 4. CCR Modeline Göre Referans Sıklıkları

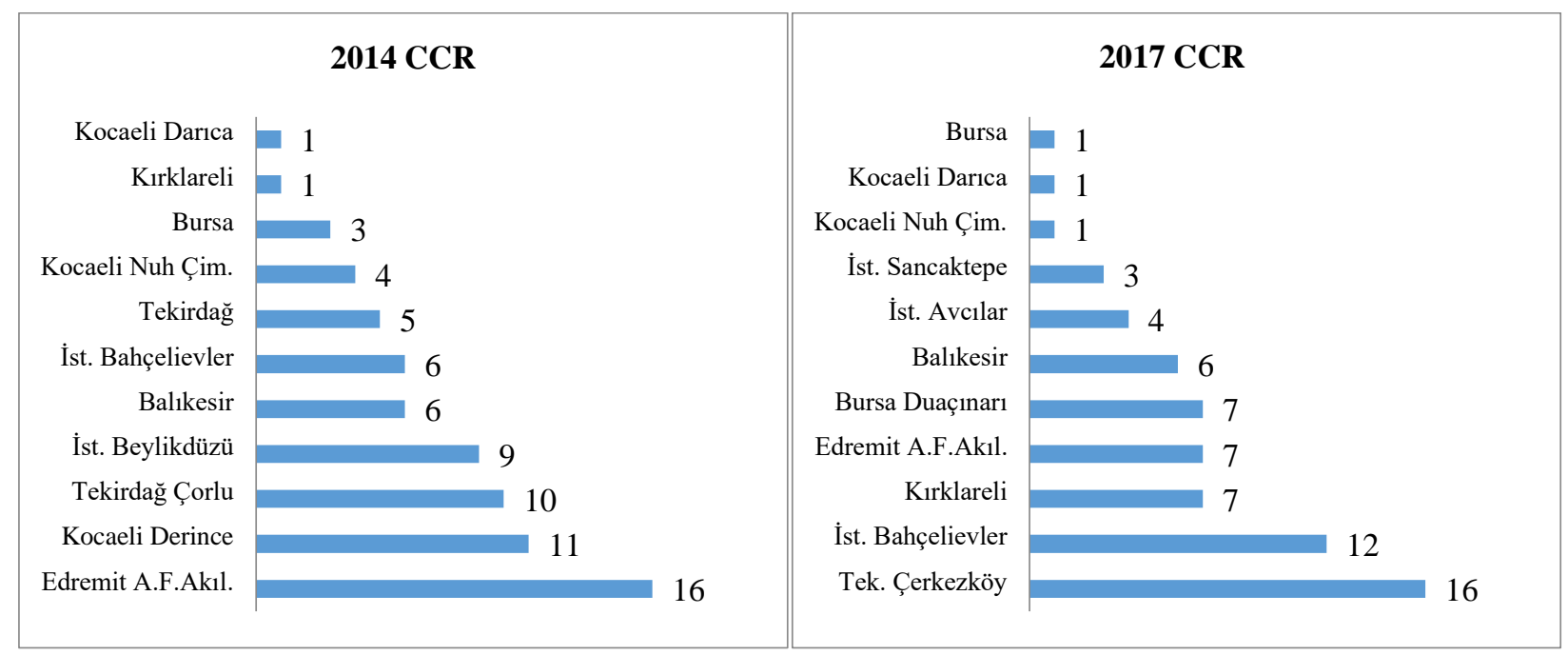

2017 CCR sonuçları incelendiğinde etkin olmayan KVB'ler ve etkin olmaları için referans alabilecekleri tam etkin KVB'ler Tablo 5'de gösterilmiştir. Örneğin 2017 CCR sonuçlarına göre \%66,2 VZA analiz skoru ile en verimsiz KVB gözüken İstanbul Ataşehir ADSH, verimli duruma geçebilmek için \%138 oranında İstanbul Bahçelievler ADSM, $\% 10$ oranında Balıkesir ADSM ve \%21,9 oranında Tekirdağ Çerkezköy ADSM'yi referans almalıdır. İstanbul Tablo 5. Etkin Olmayan KVB'lerin Referans Kümeleri (2017 CCR Sonuçlarına Göre)

\begin{tabular}{|c|c|c|c|c|c|}
\hline KVB & $\begin{array}{c}\text { CCR } \\
\text { Skoru }\end{array}$ & Referans Kümesi & KVB & $\begin{array}{c}\text { CCR } \\
\text { Skoru }\end{array}$ & Referans Kümesi \\
\hline Ataşehir & 0,662 & $\begin{array}{c}\text { M2(1,382); M14(0,101); } \\
\text { M32(0,219) }\end{array}$ & Göztepe & 0,744 & $\begin{array}{c}\text { M11(0,386); M2(0,287); } \\
\text { M32(0,148); M15(0,140); } \\
\text { M23(0,224) }\end{array}$ \\
\hline Bandirma & 0,884 & $\begin{array}{c}\text { M18(0,117); M19(0,103); } \\
\text { M15(0,093) }\end{array}$ & İnegöl & 0,933 & $\begin{array}{c}\text { M19 }(0,125) ; \text { M15(0,881); } \\
\text { M25 }(0,265)\end{array}$ \\
\hline Beykoz & 0,938 & $\begin{array}{c}\text { M2(0,111); M14(0,054); } \\
\text { M32(0,624) }\end{array}$ & Kartal & 0,950 & $\begin{array}{c}\text { M32 }(0,495) ; \text { M19 }(0,002) ; \\
\text { M23 }(2,388)\end{array}$ \\
\hline Beylikdüzü & 0,930 & $\begin{array}{c}\text { M2(0,239); M32(0,710); } \\
\text { M5(0,080) }\end{array}$ & Körfez & 0,847 & $\begin{array}{c}\text { M2(0,033); M32 }(0,457) ; \\
\text { M15(0,139) }\end{array}$ \\
\hline Bilecik & 0,928 & $\begin{array}{l}\text { M2(0,106); M14(0,125); } \\
\text { M32(0,274) }\end{array}$ & Lüleburgaz & 0,898 & $\begin{array}{l}\text { M11 }(0,094) ; \text { M32 }(0,144) ; \\
\text { M15 }(0,391) ; \text { M23 }(0,188)\end{array}$ \\
\hline Çanakkale & 0,698 & $\begin{array}{l}\text { M32 }(0,100) ; 19(0,079) \text {; } \\
\text { M15(0,412); 23(0,554) }\end{array}$ & Okmeydanı & 0,845 & $\begin{array}{c}\text { M2(2,539); M23(1,707); } \\
\text { M5(0,342) }\end{array}$ \\
\hline Çekmeköy & 0,985 & $\begin{array}{l}\text { M2(0,027); M32(0,868); } \\
\text { M23(0,363) }\end{array}$ & Sakarya & 0,951 & $\begin{array}{c}\text { M32(0,936); M26(0,061); } \\
\text { M15(1,022) }\end{array}$ \\
\hline Çorlu & 0,861 & M14(0,034);M32(1,469) & Tekirdağ & 0,873 & $\begin{array}{c}\text { M2(0,427); M14(0,104); } \\
\text { M19(0,325) }\end{array}$ \\
\hline D.A.H. Ceylan & 0,825 & $\begin{array}{c}\text { M2(0,022); M32(0,538); } \\
\text { M5(0,019) }\end{array}$ & Topçular & 0,848 & M11(0,667); M2(0,098) \\
\hline Derince & 0,895 & $\begin{array}{c}\text { M11(0,230); M2(0,058); } \\
\text { M32(0,283) }\end{array}$ & Yalova & 0,977 & $\begin{array}{c}\text { M32(0,110); M19(0,374); } \\
\text { M23(0,348) }\end{array}$ \\
\hline Edirne & 0,770 & $\begin{array}{c}\text { M14(0,005); 32(0,548); } \\
\text { M19(0,275) }\end{array}$ & & & \\
\hline
\end{tabular}

Süper verimlilik (süper efficiency) analizleri kullanılarak verimli hastaneler arasındaki farklılıklar ortaya konmuştur. 2017 y1lı CCR modeli süper etkinlik analizi sonuçlarına göre; etkin hastaneler kendi arasında üstünlük sıralamasına tabii tutulduğunda Balıkesir Edremit A.F. Akıllığlu ADSM $\% 141,57$ ile en verimli KVB, İstanbul Bahçelievler ADSM $\% 137,59$ ile en verimli 2. KVB ve Balıkesir ADSM \%126,87
Ataşehir ADSH yaklaşık olarak; \%33,8 oranında ünit sayısını ve ilave olarak \%35,6 oranında toplam diş hekimi sayısını azaltmalıdır. Ayrıca \%6,67 oranında diş çekimi sayısını, \%2,74 oranında kanal tedavisi yapılan diş sayısını, $\% 57,82$ oranında hareketli protez parça sayısını artırmalıdır. 
referans gösterilmemiș olmasını, etkinlik sınırının çok az üstünde olmasına bağlayabiliriz. Tablo 6'da 2017 yılında etkin olan illerin CCR modeline göre süper etkinlik analiz sonuçları, büyükten küçüğe doğru sıralı olarak verilmiştir.

Tablo 6. 2017 Yı1ı CCR Modeline Göre Verimli KVB'lerin Süper Etkinlik Siralaması

\begin{tabular}{|l|c|}
\hline \multicolumn{1}{|c|}{ KVB Adı } & Skoru \% \\
\hline Edremit A.F. Akıllı̆̆glu & $141,57 \%$ \\
\hline Bahçelievler & $137,59 \%$ \\
\hline Balıkesir & $126,87 \%$ \\
\hline Nuh Çimento San. Vakfı & $118,68 \%$ \\
\hline Çerkezköy & $117,25 \%$ \\
\hline Kırklareli & $114,12 \%$ \\
\hline Duaçınarı & $110,98 \%$ \\
\hline Sancaktepe & $110,92 \%$ \\
\hline Avcılar & $106,03 \%$ \\
\hline Darıca & $105,83 \%$ \\
\hline Bursa & $105,30 \%$ \\
\hline Güngören & $103,15 \%$ \\
\hline
\end{tabular}

2014 yılı CCR modeli çalışma sonuçlarına göre, merkezlerin verimli olabilmesi için; girdi değişkenleri olan ünit sayısını $\% 16,1$ ve toplam diş hekimi sayısını \%13,96 oranında azaltmaları gerekmektedir. Ayrıca çıktı değişkenlerinden diş çekimi sayısında $\% 7,6$, sabit protez üye sayısında $\% 10,4$, hasta sayısında \%9,68, dolgu tedavisi sayısında \%7,6, hareketli protez parça sayısında \%17,62, kanal tedavisi sayısında \%14,21 oranında arttırmaları gerekmektedir. 2017 yılı CCR modeli çıktılarına bakıldığında ise, merkezlerin verimli olabilmesi için; girdi değişkenleri olan ünit sayısını $\% 19,76$ ve toplam diş hekimi sayısını \%14,88 oranında azaltmaları gerekmektedir. Ayrıca çıktı değişkenlerinden diş çekimi sayısında $\% 14,5$, sabit protez üye sayısında $\% 14,36$, hasta sayısında \%14,82, dolgu tedavisi sayısında \%5,39, hareketli protez parça sayısında \%14,24, kanal tedavisi sayısında \%2,14 oranında arttırmaları gerekmektedir. Gerekli artış ve azalışlar Tablo 7'de gösterilmiştir.

Tablo 7. Gerekli Artış ve Azalışlar

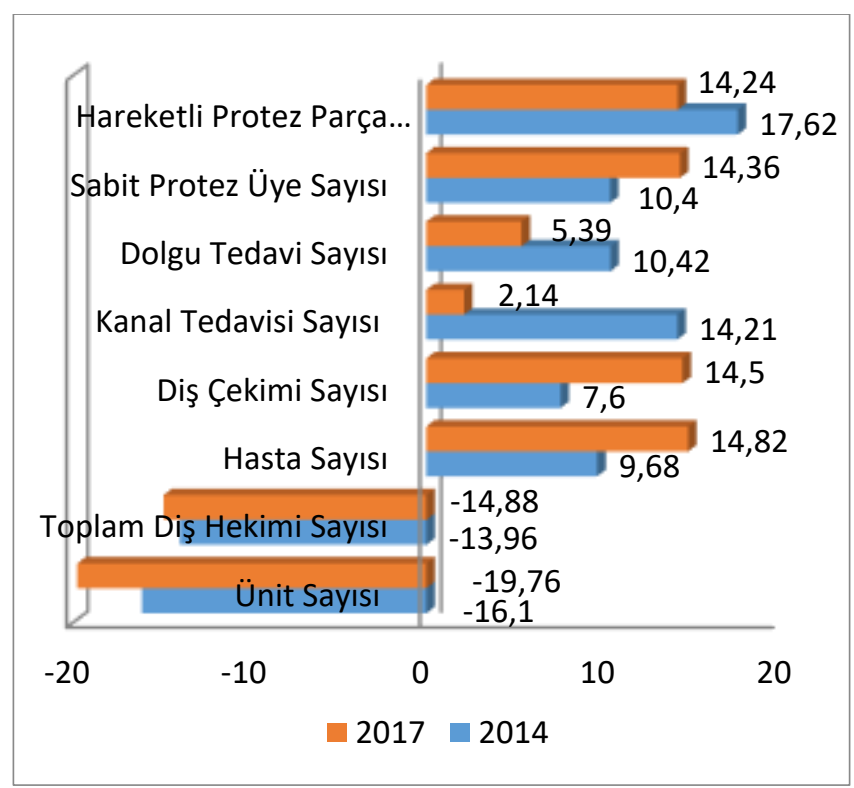

ADSM'lerin 2017 yılındaki VZA CCR modeli sonuçları ile girdi-çıktı değişkenleri arasındaki ilişki Tablo 8'de verilmiştir. Regresyon analizinden ulaşılan sonuçlarına göre $\mathrm{p}<0,05$ olduğu için girdi ve çıktı değiş̧kenleri etkinlik skoru değişiminin \%71,1'ini açılamaktadır. Girdi değişkenlerinden ünit sayısı $(\beta=-1,223)$ ve toplam diş hekimi sayısının $(\beta=-2,944)$ bağımlı değişken olan 2017 CCR skorları üzerinde negatif etkiye sahip oldukları görülmüştür. Ayrıca çıktı değişkenlerinin ise tamamının etkinlik skorları üzerinde pozitif etki yaptıkları tespit edilmiştir.

Tablo 8. VZA Sonuçlarının (CCR Modeli) Girdi-Çıktı Değişkenleri İlişkisi (2017)

\begin{tabular}{|c|c|c|c|c|c|c|c|c|c|}
\hline Değişken & B & $\begin{array}{l}\text { Std. } \\
\text { Error }\end{array}$ & Beta & $\mathbf{t}$ & Sig. & $\mathbf{R}$ & $\mathbf{R}^{2}$ & $\begin{array}{c}\text { Adjusted } \\
\mathbf{R}^{2}\end{array}$ & $\mathbf{P}$ \\
\hline Ünit Sayısı & $-0,304$ & 0,184 & $-1,223$ & $-1,653$ & 0,111 & & & & \\
\hline Toplam Diş Hekimi Sayısı & $-0,720$ & 0,209 & $-2,944$ & $-3,447$ & 0,002 & & & & \\
\hline Hasta Sayı1 1 & 0,000 & 0,000 & 0,824 & 0,929 & 0,362 & & & & \\
\hline Diş Çekimi Sayısı & 0,000 & 0,000 & 0,112 & 0,206 & 0,839 &, $843^{\mathrm{a}}$ & 0,711 & 0,615 &, $000^{\mathrm{b}}$ \\
\hline Kanal Tedavisi Sayısı & 0,001 & 0,000 & 1,113 & 3,131 & 0,005 & & & & \\
\hline Dolgu Tedavi Sayısı & 0,000 & 0,000 & 0,977 & 2,695 & 0,013 & & & & \\
\hline Sabit Protez Üye Sayısı & 0,000 & 0,000 & 0,823 & 1,793 & 0,086 & & & & \\
\hline Hareketli Protez Parça Sayısı & 0,001 & 0,001 & 0,370 & 1,132 & 0,269 & & & & \\
\hline
\end{tabular}

a. Bağımlı Değişken: 2017 CCR

b. Öngösterge: (Sabit), hareketliprotez, dişçekimi, dolgu, kanaltedavi, sabitprotez, unitsayısı, hekimsayısı, toplamhastasayısı 


\section{Tartışma}

VZA yöntemi, çok farklı sektörlerde kullanılan bir yöntem olsa da literatüre bakıldığında hastanelerde çalışılmasına da sıklıkla rastlamaktayız. Benzer girdi ve çıktılarla hizmet sektöründe faaliyette bulunan hastanelerde, verimlilik kıyaslaması yapabilmek hastane yöneticileri açısından da önemli neticeler doğurmaktadır. Yöneticiler, diğer hastaneler arasında hangi açıdan üstün veya yetersiz olduklarını görebilmekte ve önlemler alabilmektedirler. Literatürde VZA kullanılarak hastanelerde yapılan analizler ve sonuçlarından bazı örnekler aşağıda sıralanmıştır.

1994 yılında VZA'nden yararlanılarak ulaşılan sonuçlara göre Türkiye'deki, araştırmaya dahil edilen 573 hastane içerisinden sadece 54 tanesinin verimli bulunduğu Ersoy vd. tarafindan tespit edilmiştir (Ersoy vd., 1997: 71).

Şahin (1998) tarafından; Sağlık Bakanlığına bağlı hastanelerin KVB olarak seçildiği, illere göre göreceli teknik verimlilik düzeylerini hesaplamak ve elde edilen bulgular ışı̆̆ında verimsiz olan illerin verimsizlik kaynaklarını analiz etmek amaciyla kaleme alınan doktora tezinde, CRS modeline göre illerin $\% 82,5$ ve VRS modeline göre ise illerin \%55'inin göreceli olarak verimsiz olduğu bulunmuștur. Çalışma sonucunda, personel ile döner sermaye girdilerindeki toplam verimsizliğin finansal boyutu 121,2 milyon dolar olarak hesaplanmıştır (Şahin, 1998: 1).

1999 yılında yapılan çalışmada Al-Shammari, Ürdün'deki Sağlık Bakanlığına bağlı 15 hastanenin 1991-1993 y1lları arasındaki verimliliklerini incelemiştir. 1991 yılında 8, 1992 yılında 6, 1993 yılında ise 4 hastanenin verimsiz olduğu bulunmuştur (Al-Shammari, 1999: 879-886).

Linna vd. tarafından Finlandiya Sağlık Dairesi’nin 1995 yılı raporunu kaynak alarak, 228 tane ağız ve diş sağlığı poliklinik hizmeti sunan hastanede yapılan VZA ve maliyet etkililik analizi sonucunda, farklı belediye sinırları içerisindeki merkezler arasında önemli farkll1ıklar olduğu, maliyet etkinliği seviyesinin \%20-\%30 arasında çıktı ğı, girdi tahsisinin daha fazla insan gücüne kaydırılmasının maliyet verimliliğini artırmayacağı sonucuna ulaşılmıştır (Linna vd., 2003: 343).

Tarazona vd.; Sağlık Bakanlığı'nın 2005 yılı bölgesel verilerini kullanarak, İspanya'nın Valencia (Doğu İspanya) bölgesindeki 22 hastanenin sadece 3 biriminde (genel cerrahi, göz hastalıkları ve ortopedi) VZA analizi ile verimlilik ölçümü yapmışlardır. Genel cerrahi alanında 14 hastane, göz hastalıklarında 12, ortopedi servisinde ise 16 hastanenin etkin çalışmadığı sonucuna varılmıştır (Tarazona vd., 2010: 1095-1099).

Sezen ve Gök (2009), VZA yöntemi ile hastane verimliliklerinin incelenmesini amaçladıkları çalışmalarında, Türkiye'deki hastane verimliliklerinin sahipliklerine göre anlamlı bir şekilde farklılaştığını söylemişlerdir.

Leleu ve ark. İtalya'da bulunan 138 hastanenin performansını değerlendirmiş, etkinlik skorlarının 0,59 ile 0,71 arasında değişiklik gösterdiğini tespit etmişlerdir (Leleu vd., 2014:235).

Bal ve Bilge tarafindan 35 hastanede yapilan performans değerlendirmesinde; CCR modeline göre 13, BCC modelinde 20, ölçek etkinliğinde ise 18 hastanenin \%100 verimli olduğu sonucu elde edilmiştir. Skorların ortalaması; CCR 0,88 , BCC 0,93 ve ölçek etkinliğinde 0,95 olarak bulunurken, 22 hastanenin de etkinlik sinırı altında olduğu belirlenmiştir (Bal ve Bilge, 2013:7-11).

Mujasi ve ark. tarafindan Uganda'da 17 hastanenin performansı değerlendirilmiş, 3 hastane hem teknik hem de ölçek etkinliğinde verimli iken 14 hastane ise verimsiz olarak bulunmuştur. CCR ölçeğinde en az verimlilik skoru 0,431 olarak, BCC modelinde ise en düşük verimlilik skoru 0,523 olarak göze çarpmaktadır (Mujasi vd., 2016: 13-14).

Yiğit ve Esen (2017), Pabon Lasso Modeli ve VZA yöntemi ile Antalya Kamu Hastaneleri Birliği'ne bağlı hastanelerin performans düzeylerini ölçmeyi amaçladıkları araştırmada; Pabon Lasso modeline göre hastanelerin \%51'nin, VZA yöntemine göre ise hastanelerin \%67'sinin verimli olduğu tespit edilmiştir.

Kutlar ve Salamov (2016); Azerbaycan Cumhuriyeti, Sağlık Bakanlığı bünyesinde faaliyet gösteren, uzman doktor sayısı 100'ün üstünde olan 36 farklı ildeki hastanelerin, 2013 yılındaki etkinlik seviyelerini girdi odaklı VZA yöntemi ile belirlemişlerdir. Ortalama etkinlik puanı; CCR modelinde $\% 82$, BCC modelinde \%92 olarak tespit edilmiştir. CCR sonucunda 11, BCC modelinde ise $19 \mathrm{KVB}$ etkin bulunmuştur.

Bugüne kadarki çalışmalara bakıldığında, hastaneler veya aynı hastanenin farklı bölümleri arasında yapılan araştırmaların yoğunlukta olduğu görülmüştür. ADSM'leri kaynak alan araştırmalar olsa da, farklı yıllara ait aynı girdi/çıktıların analize tabii tutulmasıyla elde edilen sonuçları karşılaştıran bir araştırmaya literatürde rastlanılamamıştır. 2014 ve 2017 yıllarına ait aynı KVB'ler için kıyaslanabilir neticeler içermesinden dolayı araştırmanın özgün olduğu düşünülmüştür. VZA yöntemi ile performans ölçümleri yapılan ADSM'leri konu edinen aşağıdaki çalışmalara ulaşılmıştır.

"Cumhuriyet Üniversitesi Diş Hekimliği Fakültesi'nin Veri Zarflama Analizi Yöntemiyle Göreceli Etkinlik Analizi" isimli çalışmada Gülcü ve ark., fakültenin 6 anabilim dalının 1999/2000/2001 yıllarındaki etkinliklerini kıyaslamışlardır. Birbiri ardina 3 yll boyunca Endodonti, Pedodonti ve Periodontoloji bölümleri verimli çıkmıştır. 1999 yılında Ağız Diş Çene Hastalıkları Cerrahisi Bölümü $(0,97)$ tek verimsiz bölüm gözükmektedir. 2000 yllında Protetik Diş Tedavisi Bölümü 0,91 skoruyla, Ağız Diş Çene Hastalıkları Cerrahisi Bölümü 0,89 skoruyla verimsiz olmuşlardır. 2001 yılında ise Ağız Diş Çene Hastalıkları Cerrahisi Bölümü 0,87 , Ortodonti bölümü skoru 0,91 VZA puanı ile verimsiz olan anabilim dalları olarak bulunmuştur (Gülcü vd., 2004: 97-99).

Öner (2010) tarafindan 2008 ve 2009 y1lı verileri ile Sağlık Bakanlığına bağlı 2 ADSH ve 26 ADSM'nin verimlilikleri değerlendirilmiştir. Sonuçta 2008 yllında 28 kurumdan \%53,57'sinin, 2009 yılında ise \%71,43'ünün etkin olduğu tespit edilmiştir. 2008 yılında ortalama etkinlik skoru $106,21 \%$ iken 2009 yılında ortalama etkinlik skoru $\% 21,12$ 'lik artışla 127,34\% olarak bulunmuştur.

Özdemir (2011), benzeşik girdi ve çıktı değişkenlerine sahip olan, ayrıca eşdeğer yönetim şekliyle idare edilen 115 ADSM'nin etkinliği üzerine bir çalışma yürütmüştür. 2009 yılına ait verilerle yapılan araştırma sonucunda SB'na ait 
ADSM'lerin CRS modeli teknik verimlilik analizi sonucunda 45'i (\%39, ' 'i) verimli, 70'i (\%60,9'u) verimsiz olduğu anlaşılmıştır. VRS modeli teknik verimlilik analizlerine göre ise; 115 ADSM'nin 65'i (\%56,5'i) verimli, 50 'si (\%43,5'i) verimsiz bulunmuştur.

Arslan (2017) “Ağız Diş Sağlığı Hastanelerinin (ADSH) Veri Zarflama Analizi (VZA) Yöntemiyle Teknik Verimliliklerinin Ölçülmesi” isimli yayımlanmış yüksek lisans tezinde, 2015 y1lı verileriyle 15 tane ADSH'nin etkinlik düzeylerini incelemiştir. En düşük etkinlik skoruna sahip hastanenin puanının 0,89 şeklinde bulunduğu çalışmada, CCR model sonuçlarına göre 4 ADSH'nin verimli olmadığı tespit edilmiştir.

2018 yılında 21 tane ADSH üzerinde VZA kullanılarak yapılan çalışmada, CCR Modeli için etkin ADSH sayısı 15 iken BCC Modeli için etkin ADSH sayısı 16 olarak hesaplanmıștır. CCR modelinde en düşük etkinlik skoru 0,72 ile Şanlıurfa ADSH, BCC modelinde ise 0,88 skor ile Malatya ADSH olmuştur (Kıraç ve Kıraç, 2018: 103).

Şahin ve İlgün; Türkiye'de ki ADSM performanslarını il bazında VZA analizi ile değerlendirmişlerdir. Araştırmada; girdi olarak ünit sayısı ve hekim sayısı; çıktı olarak ise poliklinik sayısı, diş çekimi sayısı, kanal tedavisi yapılan diş sayısı, dolgu yapılan diș sayısı, cerrahi müdahale yapılan hasta sayıs1, protez yapilan hasta sayısı, flor uygulanan hasta sayısı ve fissür sealant yapılan hasta sayısı alınmıştır. Sağlık Bakanlığı'nın 2014 yılı istatistik raporlarını kaynak alan analizlerden, CCR sonuçlarına göre 18 il verimli olarak bulunurken, 63 ilin verimsiz olduğu sonucuna varılmıştır Verimli illerde yaklaşık olarak ortalama ünit sayısı 138 ve diş hekimi sayısı 133'tür. Türkiye'deki 81 ilin tamamı düşünüldüğünde, aynı durum sırasıyla 90,9 ve 85,9 olarak bulunmuştur (Şahin ve İlgün, 2018: 4).

\section{Sonuç}

Yukarıda verilen örneklere paralel olarak, bu çalışmada elde edilen sonuçları şu şekilde özetleyebiliriz. Yıllar içerisinde ADSM'lerin sayısında artış olmuş, ayrıca genel olarak merkezlerin ünit sayıları, hasta sayıları, uzman hekim sayıları gibi bütün girdi/çıktı değişkenlerinde de yükselmeler meydana gelmiştir. Örneğin 2014 y1lında 33 KVB için 4.048.453 olan toplam hasta sayısının 2017 yılında artarak 4.752.961 olduğu görülmektedir. 2014 ve 2017 yıllarının her ikisinde de CCR sonuçlarına göre $33 \mathrm{KVB}$ içerisinden 12 tanesi verimli çıkmıştır. BCC sonuçları değerlendirildiğinde ise 2014 yll için 19, 2017 yll için 18 KVB'nin verimli çalıştığı görülmüştür. BCC modelinde, CCR modeline kıyasla daha fazla ADSM'nin etkin olduğu görülmektedir. $\mathrm{Bu}$ durumun sebebi; BCC modelinin CCR modeline göre, ölçeğe göre sabit getiri yerine ölçeğe göre değişken getiri kullanması nedeniyle verimlilik sonuçlarının yüksek çıkması olarak açıklanabilir.

2014 yılında 0,909 olan CCR verimlilik ortalamasının, 2017 y1lında 0,916'ya çıkarak yükseldiği tespit edilmiştir. Ölçek verimliliği ortalaması hem 2014 hem 2017 yıllarında \%96 olarak bulunmuştur.

2014 ve 2017 yıllarının CCR modeli çıktılarının her ikisinde de etkin olduğu sonucuna varılan Tekirdağ Çerkezköy ADSM, 2014 yılında hiçbir merkez tarafından referans alınmazken 2017 yılında 16 merkez tarafindan referans alınarak en çok örnek alınması gereken KVB olmuştur.
Tekirdağ Çerkezköy ADSM, girdi değişkenlerinden ünit sayısını 25'den 28'e ve toplam diş hekimi sayısını 22'den 29'a çıkartmıştır. Girdi değişkenlerindeki artış sınırlıyken, çıktı değişkenlerinde yüksek oranda artışlar olduğu söylenebilir. Örneğin; hasta sayıs1 84.882 'den 125.495 'e, kanal tedavisi sayıs 8.325 'ten 14.599'a ve dolgu sayıs1 31.797'den 59.559'a çıkmıştır. Bursa ADSM ve Kocaeli Darıca ADSM'nin her ikisi de hem 2014 hem 2017 yıllarında yalnızca 1 hastane tarafindan referans alınmaktadır.

2014 ve 2017 yılları CCR model sonuçları birlikte ele alındığında; verimli olmak için KVB'lerin yapmaları gereken artış ve azalışlarda kanal tedavisi sayısı dikkat çekmektedir. 2014 yılına göre \%14,21 artırılması gereken kanal tedavisi yapılan diş sayısı 2017 yılına gelindiğinde $\% 2,14$ artırmanın yeterli olabileceği anlaşılmaktadır. KVB'leri aynı olmasına karşın 2014 ve 2017 yılları kıyaslandığında, 2014 yılında 33 KVB'nde yapılan toplam kanal tedavisi sayıs1 388.524 iken, 2017 y1lında bu rakam 596.534'e yükselmiştir. Analize konu olan 3 yıllık süre zarfında ADSM'lerin kanal tedavisi sayısında artış olduğu ve bu artışın performanslarına olumlu yansıdığını söyleyebiliriz. Bir başka belirgin fark, dolgu tedavisi uygulanan diş sayısında göze çarpmaktadır. 2014 yılında $\% 10,42$ artırılması gereken dolgu yapılan diş sayısı, 2017'ye gelindiğinde \%5,39 oranında artırılması gerekmektedir. 33 KVB'nin 2014 yılındaki ürettiği toplam dolgu sayısı 1.674.911 olarak bulunmuşken, 2017 yılında bu say1 2.410.827 olarak karşımıza çıkmaktadır. Aynı şekilde ADSM'lerin dolgu tedavisi sayısında önemli bir yükselmenin olduğu ve bunun verimliliklerinde önemli olduğu anlaşılmaktadır. Hem 2014 hem 2017 yıllarının girdi değişkenlerinde (ünit sayısı ve toplam diş hekimi sayısı) azaltma yoluna gidilmesi gerektiği sonucuna varılmıştır.

2014 yılı CCR sonuçlarına göre en düşük verimlilik skoruna sahip KVB olan Çekmeköy ADSM ve 2017 CCR sonuçlarına bakıldığında en düşük verimlilik skoruna sahip Ataşehir ADSM başta olmak üzere tüm verimsiz merkezlerin atıl olarak kullanılan kaynaklarını azaltmaları gerekmektedir. Verimsiz bulunan KVB'ler kendileri için referans gösterilen merkezleri temel alarak potansiyel iyileştirmelerde bulunmalıdırlar. Yöneticilerin; idare ettikleri merkezler için önemli sonuçlar barındıran VZA analiz sonuçlarından yararlanmaları, gerekli iyileştirmeleri yapmakta rehber olarak kullanmaları gerektiği görülmüştür. Fazla kullanılan kaynaklar tespit edilmeli ve elde edilen çıktılar yorumlanmalıdır. Referans kümesinde yer alan KVB'lerin diğer merkezlerce örnek alınması, hangi girdi veya çıktılarda ne oranda değişiklik yapılması gerektiği konularında model oluşturması açısından değerli bilgiler içermektedir. Etkin oldukları anlaşılan merkezlerin bunu korumak için gerekli eylem planlarını hazırlamaları gerekmektedir. ADSM yöneticileri, veriler ve sonuçları kendi hastaneleri açısından değerlendirerek gerekli önlemleri almalıdır.

\section{Kaynakça}

Ağaç, G. \& Baki, B. (2016), Sağlık Alanında Çok Kriterli Karar Verme Teknikleri Kullanımı: Literatür İncelemesi, Hacettepe Sağlık İdaresi Dergisi, 19(3):343-63. 
Ağırbaş, İ. (2014), Sağlık Kurumlarında Finansal Yönetim ve Maliyet Analizi, Siyasal Kitapevi, Ankara.

Allen, P.F. (2003), Assessment of Oral Health Related Quality of Life, Health and Quality of Life Outcomes, 1: 40.

Al-Shammari, M. (1999), A Multi-criteria Data Envelopment Analysis Model For Measuring the Productive Efficiency of Hospitals, International Journal of Operations \& Production Management, 19(9), 879-891.

Arslan, B. (2017), A $\breve{g} l z$ Diş Sağllğg Hastanelerinin (ADSH) Veri Zarflama Analizi (VZA) Yöntemiyle Teknik Verimliliklerinin Ölçülmesi, Dokuz Eylül Üniversitesi Sosyal Bilimler Enstitüsü, İşletme Anabilim Dalı, Hastane ve Sağlık Kuruluşları Yönetimi Programı, Yüksek Lisans Tezi, İzmir.

Babacan, A. (2006), Türkiye'deki Üniversitelerde VZA Yöntemiyle Verimlilik Analizi. Cumhuriyet ÜniversitesiSosyal Bilimler Enstitüsü, Doktora Tezi, Sivas.

Bal, V. \& Bilge, H. (2013), Eğitim ve Araştırma Hastanelerinde Veri Zarflama Analizi İle Etkinlik Ölçümü. Manas Sosyal Araştırmalar Dergisi, 2(2):1-14.

Cooper, W. W. (2005), Origins, Uses of and Relations Between Goal Programming and Data Envelopment Analysis, Journal of Multi-Criteria Decision Analysis, 13(1), 3-11.

Çolak, H., Dülgergil, T. Ç. \& Serdaroğlu, İ. (2010), Ağız ve Diş Hastalıklarının Medikal, Psikososyal ve Ekonomik Etkilerinin Değerlendirilmesi, Sağllkta Performans ve Kalite Dergisi, 2, 63-89.

Ersoy, K., Kavuncubasi, S., Ozcan, Y. A. \& Harris, J. M. (1997), Technical Efficiencies of Turkish Hospitals: DEA Approach, Journal of Medical Systems, 21(2), 67-74.

Farrell, M. J. (1957), The Measurement of Productivite Efficiency, Journal of The Royal Statistical Society, Series A (General), 120(3), 253-290.

Flokou, A., Aletras, V. \& Niakas, D. (2017). A WindowDEA Based Efficiency Evaluation of the Public Hospital Sector in Greece During the 5-Year Economic Crisis. PloS one, 12(5), e0177946.

Gülcü, A., Coşkun, A., Yeşilyurt, C., Coşkun, S. \& Esener, T. (2004), Cumhuriyet Üniversitesi Diş Hekimliği Fakültesi'nin Veri Zarflama Analizi Yöntemiyle Göreceli Etkinlik Analizi, C. Ü. Íktisadi ve Idari Bilimler Dergisi, Cilt.5, Sayı. 2

https://khgm.saglik.gov.tr/TR,40113/kamu-hastaneleriistatistik-raporu--2017.html, Erişim Tarihi: $15 / 06 / 2019$

Kavuncubaşı, Ş. \& Ersoy, K. (1995), Hastanelerde Teknik Verimlilik Ölçümü, Amme İdare Dergisi, 28(3).

Kıraç, Y. \& Kıraç, S. (2018), Veri Zarflama Analizi Yaklaşımını Kullanarak Ağız ve Diş Sağlığı
Hastanelerinin (ADSH) Verimlilik

Değerlendirmesi, Journal of International Management, Educational and Economics Perspectives, 6 (2) 90-105.

Kutlar, A. \& Kartal, M. (2004), Cumhuriyet Üniversitesinin Verimlilik Analizi: Fakülteler Düzeyinde Veri Zarflama Yöntemiyle Bir Uygulama, Kocaeli Üniversitesi Sosyal Bilimler Enstitüsü Dergisi, (8)/ 2: 49-79.

Kutlar, A. \& Salamov, F. (2016), Azerbaycan Kamu Hastanelerinin Etkinliğinin VZA Uygulaması ile Değerlendirilmesi. Kocaeli Üniversitesi Sosyal Bilimler Dergisi, (31), 1-17.

Leleu, H., Moises, J. \& Valmanis, V. G. (2014), How Do Payer Mix and Technical Inefficiency Affect Hospital Profit? A Weighted DEA Approach. Operations Research for Health Care, 3:231-37.

Linna, M., Nordblad, A. \& Koivu, M. (2003), Technical and Cost Efficiency of Oral Health Care Provision in Finnish Health Centres, Social Science \& Medicine, 56(2), 343-353.

Locker, D. (1997), Concepts of Oral Health, Disease and The Quality of Life. In: Measuring Oral Health and Quality of Life, Edited by: Slade GD, Chapel Hill: University of North Carolina: Dental Ecolog: 1124.

Mujasi, P., Asbu, AZ. \& Puing-Junoy, P. (2016), How Efficient Are Referral Hospitals in Uganda ? A Data Envelopment Analysis and Tobit Regression Approach. BMC Health Services Research, 1-14.

Naveh, E. \& Stern, Z. (2005), How Quality İmprovement Programs Can Affect General Hospital Performance, International Journal of Health Care Quality Assurance, 18(4), 249-270.

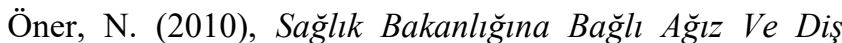
Sağlığı Kurumlarının Veri Zarflama Analizi Yöntemi Ile Performansının Değerlendirilmesi, Gazi Üniversitesi Sosyal Bilimler Enstitüsü İșletme Anabilim Dalı Hastane İşletmeciliği Bilim Dalı, Yüksek Lisans Tezi, Ankara.

Özdemir, Y. (2011), Türkiye'deki Sağlık Bakanlığı'na Bağlı

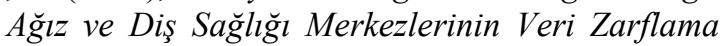
Analizi ile Göreceli Teknik Verimliliklerinin Ölçülmesi, Hacettepe Üniversitesi, SBE, Yüksek Lisans Tezi, Ankara.

Ramanathan, R. (2005), Operations Assessment of Hospitals in The Sultanate of Oman, International Journal of Operations and Production Management, 25(1), 39-54.

Sezen, B. \& Gök, M. S. (2009), Veri Zarflama Analizi Yöntemi ile Hastane Verimliliklerinin İncelenmesi, METU Studies in Development, 36(2), 383.

Sherman, H.D. (1984), Hospital Efficiency Measurement and Evaluation: Empirical Test of a New Technique, Medical Care, Vol. 22, No. 10, pp. 922938. 
Şahin, B. \& İlgün, G. (2018), Assessment of The Efficiency of Dental Services in Turkey, Health Policy and Technology, 7(2), 173-181.

Şahin, İ. (1998), Să̆lık Bakanlı̆̆ı Hastanelerinin İllere Göre Karşılaştırmalı Verimlilik Analizi: Veri Zarflama Analizine Dayall Bir Uygulama, Doktora Tezi, Hacettepe Üniversitesi Sağlık Bilimleri Enstitüsü, Ankara.

Şahin, İ. (2008), Sağlık Bakanlığı Genel Hastaneleri ve Sağlık Bakanlığına Devredilen SSK Genel Hastanelerinin Teknik Verimliliklerinin Karşılaştırmalı Analizi, Hacettepe Sağlık Iddaresi Dergisi, 11(1).

T.C. Sağlık Bakanlığı. (2016), Türkiye Kamu Hastaneleri Kurumu Rapor Bülteni 2015, Ankara.

Temür, Y. (2010), İllerin Gelişmişlik Derecelerine Göre Hastanelerin Etkinlik Analizi, Uludağ Üniversitesi Íktisadi ve İdari Bilimler Fakültesi Dergisi, XXIX(2), 1-22.

Thanassoulis, E. (1993), A Comparison of Regression Analysis and Data Envelopment Analysis as Alternative Methods for Performance Assessments,
Journal of the Operational Research Society, Vol. 44, No. 11, Great Britain.

Türk Diş Hekimleri Birliği (TDB) Yayınları (2019), Diş Hekimlerinin Çalışma Şekilleri, Kurumlarda ve Illillçelerde 2018 Yılı Dağılımı, Ankara.

WHO, (1948), Constitution of The World Health Organization, New York.

Yıldırım H. H. \& Yıldırım, T. (2011), Avrupa Birliği’ne Üyelik Sürecinde Türkiye Sağllk Sektörü, İmaj Yayınevi 2. Bask1, Ankara

Yiğit, V. \& Esen, H. (2017), Pabon Lasso Modeli ve Veri Zarflama Analizi ile Hastanelerde Performans Ölçümü Performance Measurement in Hospitals with Pabon Lasso Model and Data Envelopment Analysis, SD ̈U Să̆lık Bilimleri Enstitüsü Dergisi, $1-7$.

Yiğit, V. \& Yiğit, A. (2016), Üniversite Hastanelerinin Finansal Sürdürülebilirliği, Mehmet Akif Ersoy Üniversitesi Sosyal Bilimler Enstitüsü Dergisi, 8(16), 253-273.

Yolalan, R., (1993), İsletmelerarası Göreli Etkinlik Ölçümü, Milli Prodüktivite Merkezi Yayınları: 483, Ankara. 